HERRERO B; BLÁZQUEZ ME; CRISTÓBAL MD. 2014. Agronomic parameters assessment in hydroponic tomato crop. Horticultura Brasileira 32: 385-390. DOI - http://dx.doi.org/10.1590/S0102-053620140000400003

\title{
Agronomic parameters assessment in hydroponic tomato crop
}

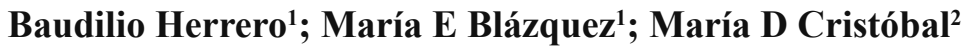

${ }^{1}$ Univ. de Valladolid, Depto. Ciencias Agroforestales (Botánica), ${ }^{2}$ Depto. Producción Vegetal y Recursos Forestales, 34004 Palencia, Espanha; baudilio@agro.uva.es; blazquez-me@hotmail.com; lcristob@uva.es

\begin{abstract}
In this study we present the results of a comparative analysis of nutrient solution (NS) recycling and non-recycling treatments in hydroponic tomato crop. The established aims are to evaluate water consumption, $\mathrm{pH}$ and conductivity variation along the productive cycle in both treatments, to establish the differences in fruit yield and to assess the viability of the recycling system. Watering times and drained nutrient solution volume were counted on a daily basis. Emitter and drained water samples from both treatments were analyzed once per week in the Agricultural Institute of Fraisoro (Gipuzkoa). Tomato samples were collected, weighed and measured three times per week once the harvest had started. There was an $8 \%$ reduction in water supply; irrigation excess was between $11-38 \%$ and water supply efficiency was $6.7 \%$ higher in the recycling treatment in comparison to the non-recycling treatment. Drainage $\mathrm{pH}$ values fluctuated from 3.9-7.6 and conductivity varied from 1.9-3.6 mS/cm. Average yield per plant was $7.17 \mathrm{~kg} /$ plant. No significant differences were found regarding fruit yield, except for the commercialized smaller size tomatoes (diameter $57-67 \mathrm{~mm}$ ) whose production was $226 \%$ higher in the non-recycling area. Fruit yield was not increased by the recycling technique in hydroponic crop. Recycling treatment viability has to be measured in terms of water and fertilizers saving and minimization of polluting waste in drainage solutions.
\end{abstract}

Keywords: Lycopersicon esculentum, hydroponic crop, no recycling, recycling, yield.

\section{RESUMEN \\ Evaluación de parámetros agronómicos en cultivo hidropónico de tomate}

En este trabajo se presentan los resultados de un análisis comparativo de los tratamientos con recirculación y sin recirculación de soluciones nutritivas en un cultivo hidropónico de tomate. Los objetivos planteados son evaluar el consumo de agua, variación del $\mathrm{pH}$ y conductividad a lo largo del ciclo productivo en ambos tratamientos, establecer las diferencias en cuanto a producción de tomates y valorar la viabilidad del sistema con recirculación. Se contabilizaron diariamente el número de riegos y el volumen de solución nutritiva drenada. Se recogieron $1 \mathrm{vez}$ por semana, muestras de agua, tanto de goteo como de drenaje, de ambos tratamientos, que se analizaban en el laboratorio agrario de Fraisoro (Zizurkil, Gipuzkoa). Iniciada la recolección, 3 veces por semana, se recogían muestras de tomates que se pesaban y calibraban. A raíz de los resultados obtenidos se concluyó que en el tratamiento con recirculación frente al de no recirculación, existe una reducción de los aportes de agua del 8\%; el exceso de riego se situó entre el 11$38 \%$ y la eficiencia en el uso del agua fue de un 6,7\% superior en el tratamiento con recirculación. El pH del drenaje osciló de 3,9-7,6 y la conductividad varió de 1,9-3,6 $\mathrm{mS} / \mathrm{cm}$. La producción media por planta fue de $7,17 \mathrm{~kg}$ por planta. No se encontraron diferencias significativas en cuanto a la producción de tomates, excepto para los tomates de menor calibre comercializados (diámetro de 57-67 mm), siendo un $226 \%$ más elevada en la zona no recirculada. La técnica de recircular las soluciones nutritivas en cultivo hidropónico de tomate no incrementó la producción de las plantas, pero su viabilidad debe ser medida en términos de ahorro de agua de riego, fertilizantes, y minimizar la generación de residuos contaminantes en soluciones de drenaje.

Palabras clave: Lycopersicon esculentum, cultivo hidropónico, no reciclado, reciclado, producción.

(Recebido para publicação em 1 de julho de 2013; aceito em 14 de agosto de 2014) (Received on July 1, 2013; accepted on August 14, 2014)

$\mathrm{R}$ esh, in 1997, described hydroponic crops as the science of soilless plant growth, though using an inert surface (gravel, sand, perlite, peat...). He also stated that water would be the authentic hydroponic crop among all cultivation methods.

The use of soilless culture in agriculture was initiated in Europe in the seventies (Alarcón, 1998).
Fertilization is an important factor in plant development. A lot of the agronomic problems in closed soilless crops come from progressive alteration of the original nutrient solution composition, mainly, due to the accumulation of certain ions such as chlorides, sulfates and sodium.

Recirculation consists of gathering leachates, formed as a result of excessive water supplies, adjusting nutritional imbalance in the solution caused by the absorption process of the plant and once that imbalance is corrected, reintroducing to the crop the resultant solution with a new one, establishing a closed system.

The need to reduce water and mineral consumption that are involved in an open soilless cultivation system 
led to the recirculation of nutrient solution (NS). However, the successful application of a closed system is more dependent on good knowledge of plant needs for water and nutrients than the open system. Water and nutrients should be supplied according to their uptake to avoid an increase or a depletion of nutrients in the recirculating NS. This way requires the increase of the frequency of NS renewal, because of electrical conductivity rising or nutrients deficiency.

Experiments carried out in Mediterranean conditions on tomato grown in a closed system using a NS recommended by the Dutch greenhouse industry (Sonneveld \& Straver, 1992) showed an accumulation of the ions less used by the crop as well as accumulation of the main macronutrients in the recirculating solution especially in the high evapotranspiration period. This accumulation imposes a high frequency of NS renewal, which led to the release of conspicuous quantities of mineral into the environment (Giuffrida \& Leonardi, 2009).

Tomato is a plant that adapts better to warm environments. It needs temperatures over $15^{\circ} \mathrm{C}$ to grow, and it is unfavorably affected by long exposures to temperatures under $10^{\circ} \mathrm{C}$. Better quality plants are obtained if night temperatures are $5.5^{\circ} \mathrm{C}$ lower than daily ones (Resh, 1997). Ideal temperature is $24-26^{\circ} \mathrm{C}$ during daytime and $18-20^{\circ} \mathrm{C}$ during the night. In the cold season time those temperatures are lower. In cold climate $\mathrm{CO}_{2}$ emissions because of heating systems have a high environmental impact that needs to be minimize (Page et al., 2011).

Water consumption reduction is necessary by means of the improvement in irrigation systems and practices; reuse of sewage water properly treated; introduction of less water demanding crops and cultivation systems. It is also necessary to control oxygen level in the recirculating solution and the presence of pathogens and possible substances emitted by the roots (Costa \& Junqueira, 2000; Graham et al., 2011).

Nitrogen excess produces softer fruits with lower sugar content and worse conservation. Nitrogen defects would provoke a delay in the plant growth.

The main aim of this study is to compare fruit yield, water consumption and $\mathrm{pH}$ and salinity variations in two different tomato hydroponic crops: a recycling system in which the consumed nutrient solution is the one used by the plant; and a non-recycling system (non-recoverable solution) in which the whole amount of water supplied is consumed. The objective is to minimize the environmental impact caused by drainage with the use of these nutrient solutions.

\section{MATERIAL AND METHODS}

The study was carried out in the facilities of the 'Caserío Pelegriñe' located in San Sebastián (Gipuzkoa), Spain $\left(43^{\circ} 18^{\prime} 24^{\prime \prime} \mathrm{N}, 02^{\circ} 02^{\prime} 22^{\prime \prime} \mathrm{W}\right.$, altitude $104 \mathrm{~m})$. The climate is warm wet Atlantic, with an average annual temperature of $13.1^{\circ} \mathrm{C}$. The frost period lasts about 15 days distributed between December and February. Annual average precipitation is $1,560.1 \mathrm{~mm}$ with a 182 days rainy period.

The test was carried out in a multitunnel greenhouse whose inner structure is made from methyl polymethacrylate slabs. The characteristics of this structure are: $85-92 \%$ transparency, extremely low diffusion power, $1.9 \mathrm{~g} / \mathrm{cm}^{3}$ density, high infra-red radiation opacity, high breaking resistance and high scratch resistance. The greenhouse surface is $3,000 \mathrm{~m}^{2}$ divided in 10 plots, 5 at each side of the central corridor. Two $280 \mathrm{~m}^{2}$ plots were selected: one for the nonrecycling tomato crop and the other for the recycling nutrient solution system.

The chosen substrate was perlite, a volcanic material that expands after a heating process at $800-1,000^{\circ} \mathrm{C}$. Perlite is a sterile, neutral or slightly alkaline substrate and with no cationic exchange capacity. It is composed by silica, aluminum oxides, iron, calcium, magnesium and sodium. The perlite used had $1.5 \mathrm{~mm}$ particle diameter and $0.105-0.125 \mathrm{~g} / \mathrm{cm}^{3}$ density, $13.4 \mathrm{~L} / \mathrm{m}^{2}$ total volume. Perlite sacks contained 30 L and sack density was 0.4 sack $/ \mathrm{m}^{2}$. The perlite sacks present an exit drainage hole on the base.

Each sack had three emitters not placed on the stem to avoid diseases. Plant density was 1.6 plants $/ \mathrm{m}^{2}, 4$ plants in each sack.

Conditions inside the greenhouse were regulated by a climate controller. The minimum temperatures to activate heating were $15^{\circ} \mathrm{C} / 18^{\circ} \mathrm{C}$ night/day and the maximum temperatures to activate zenithal ventilation were $19^{\circ} \mathrm{C} / 21^{\circ} \mathrm{C}$ night/day.

The tomato variety used in the study was Jack, hybrid F1, indefinite size and long cycle, plants with few foliage, tomatoes type Beef (fleshy), very smooth and slightly green stem. It is highly productive and especially recommendable for greenhouse culture as it is resistant to Fusarium, Verticillum, nematodes and TMV (Tobacco Mosaic Virus).

The design was simple random sampling, with 2 treatments, plot with recirculation and plot without recirculation. Each plot contained 116 bags of perlite, 12 sacks were obtained randomly (12 reps) for yield testing. The sampling unit was the mean value of the 4 plants containing each bag. For tests of $\mathrm{pH}$, conductivity, irrigation and drainage, 4 sacks were obtained at random (4 replicates) in each plot, and the sampling unit was the sack.

Plants were sown on 17/01/2012, and transplanted to the perlite sacks on 03/03/2012 (week 1), recirculation began on 03/04/2012 (week 6) and harvest was carried out between 19/05/2012 and 20/07/2012 (weeks 13-19).

$\mathrm{pH}$ and electrical conductivity readjustment were done by means of two catheters in the irrigation equipment and a weekly contrast in the recirculating solution tank to fix the fertilizer injection proportion.

In table 1 are presented the following data: irrigation water and nutrient solution composition during the test period. Irrigation water comes from a high quality, electrical conductivity and low salt content subterranean well. Present carbonates were counteracted with nitric acid.

Nutrient solution was pumped with a $3 \mathrm{~L} / \mathrm{h}$ flow during 6 minutes, during 
the whole crop cycle. Irrigation program on demand was started with recycling in one plot, and selecting another plot without irrigation recirculation, 1 month after the tomatoes were planted on the perlite substrate. Watering times were written down on a daily basis.

To analyze drainage, 4 sacks in each plot were randomly obtained and their volume was collected and measured on a daily basis.

Dripper and drainage samples from the 8 sacks were taken to analyze in the laboratory on a weekly basis: 4 repetitions/treatment (4 sacks with recycling solution and 4 sacks with non-recycling system). $\mathrm{pH}$ was determined by potentiometry and electrical conductivity was determined by conductimetry with temperature compensation. Analitic determinations were done in the laboratory Fraisoro of Zizurkil (Gipuzkoa).

For yield study, 12 sacks from each treatment were obtained at random, fruits were collected from 48 plants per treatment 3 times per week. Tomatoes were measured in 5 categories according to their diameter expressed in $\mathrm{mm}$ : measurements $>77,67-77,55-67,47-55$ $\mathrm{y}<47$; and weighed.

A variance analysis, Anova with one factor, was carried out for total fruit yield, and for fruit size based production. SAS statistical package, version 8 (SAS, 1999) was used.

\section{RESULTS AND DISCUSSION}

The weekly water consumption has fluctuated between 4.6 and $15.3 \mathrm{~m}^{3}$, with

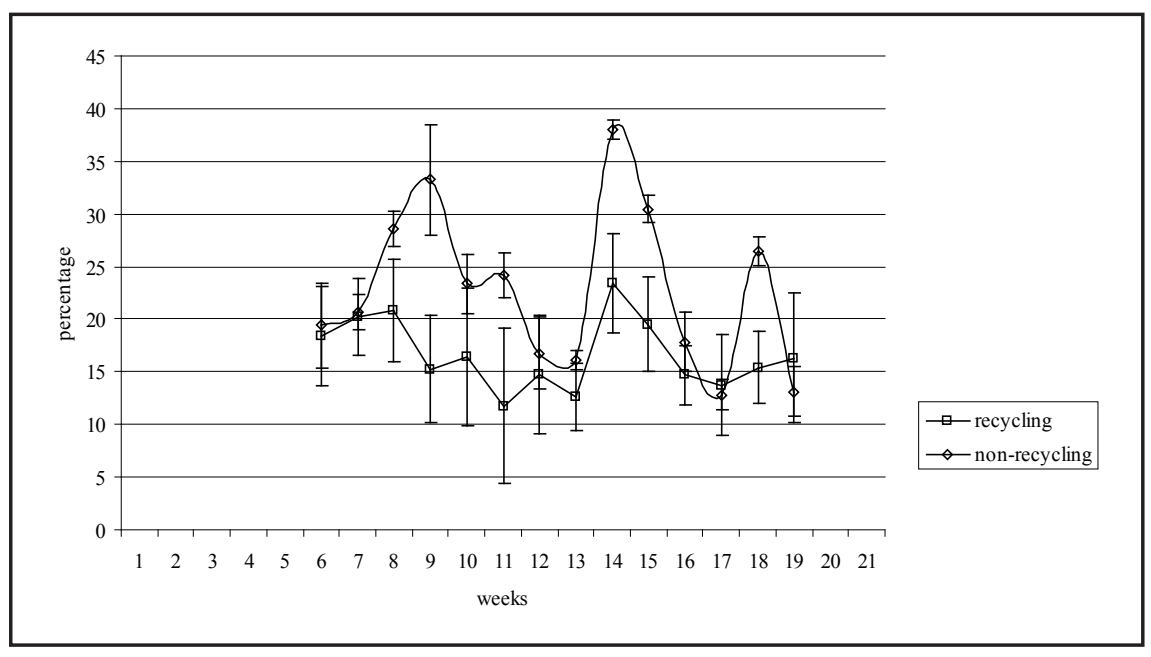

Figure 1. Average drained percentage with respect to supplied volume in the irrigation in each plot during the productive cycle (porcentaje medio drenado respecto al volumen aportado en el riego, en cada una de las parcelas durante el ciclo productivo del tomate). San Sebastián (Spain), Univ. de Valladolid, 2013.

an average of $10.8 \mathrm{~m}^{3}$ per day. Weeks with the higher number of water supply coincided with the season of highest tomato productivity. In the recycling area water supply was $8 \%$ less than in the non-recycling area, during the whole crop analyzed. The maximum was in week 13, coinciding with the start of the harvest. The following week decrease was due to a decrease of the outside temperature. During weeks 1417 surrounding temperatures were high. In weeks 20-21 there was no irrigation to remove the crop.

Exceptional needs in the nutrient solution recycling and non-recycling treatments are practically equal. Both treatments have the same tendencies. Maximum and minimum reached until week 12 could be due to outside temperature variations. Temperature variations provoke a transpiration increase and so water consumption that is faster than nutrient consumption (Casanovas, 1996).

The percentage of drained nutrient solution with respect to the supply in the irrigation was presented in figure 1. Differences were found between the sacks with and without recirculation. The mean values for the whole crop, in the recycling system $16.67 \%$ of irrigation was recovered facing the $23.26 \%$ of recovered water in the nonrecycling system. Irrigation excess, difference between emitter and drained, was $11-38 \%$. The relation water volume/ $\mathrm{kg}$ fruit yield was $3.59 \mathrm{~L} / \mathrm{kg}$ in the recycling treatment and $3.83 \mathrm{~L} / \mathrm{kg}$ in the non-recycling treatment. We observed that water usage efficiency is higher in the recycling system.

Water saving was lower than the one found by Marfà (2000) who estimated a

Table 1. Irrigation water and nutrient solution composition used in the study (composición del agua de riego y de la solución nutritiva empleada en el ensayo). San Sebastián (Spain), Univ. de Valladolid, 2013.

\begin{tabular}{|c|c|c|c|c|c|c|c|c|c|c|c|c|}
\hline & \multicolumn{5}{|c|}{ Anions (mM) } & \multicolumn{5}{|c|}{ Cations (mM) } & \multirow{2}{*}{$\mathbf{p H}$} & \multirow{2}{*}{$\underset{(\mathrm{mS} / \mathrm{cm})}{\mathrm{CE}}$} \\
\hline & $\mathrm{NO}_{3}^{-}$ & $\mathrm{H}_{2} \mathrm{PO}_{4}^{-}$ & $\mathrm{SO}_{4}=$ & $\mathrm{HCO}_{3}^{-}$ & $\mathrm{Cl}^{-}$ & $\mathrm{NH}_{4}^{+}$ & $\mathbf{K}^{+}$ & $\mathrm{Ca}^{2+}$ & $\mathbf{M g}^{2+}$ & $\mathbf{N a}^{+}$ & & \\
\hline Water & 0 & 0 & 0.91 & 4.0 & 0.5 & 0 & 0 & 2.22 & 0.15 & 0.8 & & \\
\hline Addition & 13.75 & 1.5 & 2.70 & 0 & 0 & 1.25 & 8.75 & 2.03 & 1.85 & 0 & & \\
\hline \multirow[t]{3}{*}{ Final solution } & 13.75 & 1.5 & 3.61 & 0.5 & 0.5 & 1.25 & 8.75 & 4.25 & 2.00 & 0.8 & 6 & 2.0 \\
\hline & \multicolumn{2}{|c|}{ Anions (ppm) } & & & & \multicolumn{4}{|c|}{ Cations (ppm) } & & & \\
\hline & B (III) & Mo (VI) & & & & $\mathrm{Fe}^{2+}$ & $\mathbf{M n}^{2+}$ & $\mathrm{Cu}^{2+}$ & $\mathbf{Z n}^{2+}$ & & & \\
\hline Addition & 0.5 & 0.01 & & & & 1.85 & 0.75 & 0.08 & 0.08 & & & \\
\hline Final solution & 0.5 & 0.01 & & & & 1.85 & 0.75 & 0.08 & 0.08 & & & \\
\hline
\end{tabular}




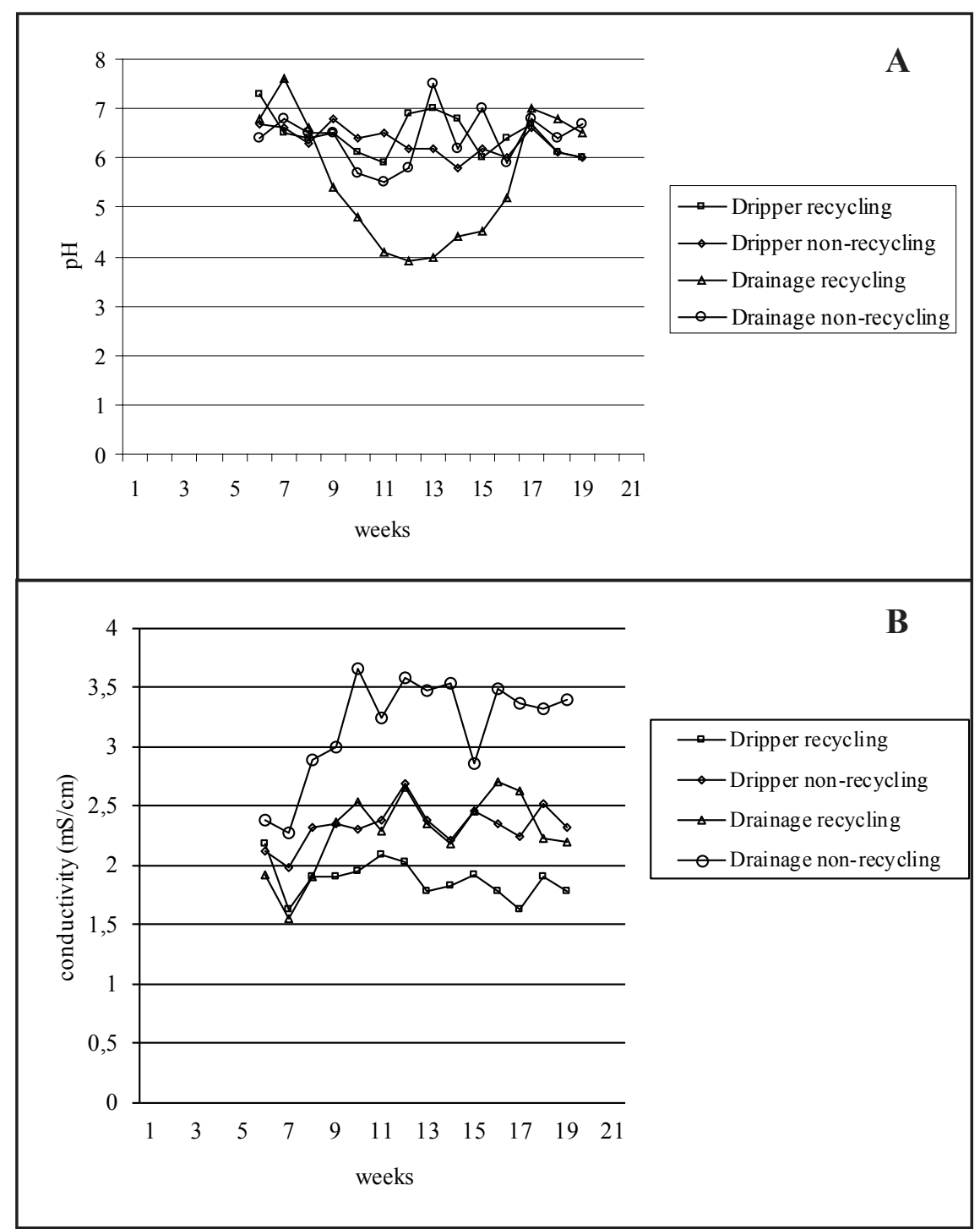

Figure 2. Weekly pH values (a) and conductivity (b) in the emitter and drainage solution in both test plots [valores semanales del pH (a) y conductividad (b) en la solución nutritiva del gotero y drenado, en las dos parcelas de estudio]. San Sebastián (Spain), Univ. de Valladolid, 2013.

10 to $50 \%$ water saving in the recycling cultures and by Dhakal et al. (2005) in tomato crop in tropical climate.

In relation to the percentage of drained nutrient solution, the observed differences between the recycling and the non-recycling system can be due to perlite particles diameter differences and to the obstruction of the emitters so not all the sacks received the same amount of nutrient solution. Drained percentage is within the reasonable range marked by Vergote \& Vermeulen (2012) that is $10-30 \%$. These percentages are variable depending on the season and the development stage of the plant.

In figure $2 a$ the emitter and drainage
$\mathrm{pH}$ variation is shown in the nutrient solution recycling and non-recycling system. Dripper $\mathrm{pH}$ fluctuated between 5.8 and 7.3. Drained solution of the sacks fluctuated between 3.9 and 7 . $\mathrm{pH}$ is higher and more imbalanced in the recycling system that follows a more constant course. The sacks with nutrient solution recirculation acidified considerably with respect to the emitter $\mathrm{pH}$.

Regarding water usage efficiency for the crop, the results are similar to that ones found by Page et al. (2011) in tomato. Pedicle activity and absorption of the different nutrients provokes $\mathrm{pH}$ and electrical conductivity changes in the lixiviated solution (Marfà, 2000). Fertigation control equipment has sensors to control these variations. Substrate $\mathrm{pH}$ can increase between 0.5 and 1 due to higher anion absorption (Casanovas, 1996). Lixiviated solution electrical conductivity was lower at the beginning of May than at the end of May which coincides with the results obtained by Feltrin et al. (2012) who estimated that in the vegetative period the plant presents high ionic absorption rates. According to Papadopoulos et al. (1999) it is very likely in greenhouse crops. Low cost fertilizers are administrated with water supply that is why maybe in the non-recycling area higher $\mathrm{pH}$ and electrical conductivity values were found.

Most of the plants prefer a $\mathrm{pH}$ value between 6 and 7 as optimal for nutrient absorption (Resh, 1997). In the case of tomato the recommended $\mathrm{pH}$ is $6.5-7$ (Zahedifar et al., 2012). pH values in the test fluctuated within a higher range.

In figure $2 b$ are shown the emitter and drainage electrical conductivity data in the nutrient solution recycling and non-recycling systems. These values fluctuated between 1.5 and 3.5 $\mathrm{mS} / \mathrm{cm}$. In both cultivation systems, an increase in nutrient solution electrical conductivity wais observed. Drained nutrient solution salinity progressively increased, more in the non-recycling system due to the salinity of the supplies. Drainage salinity fluctuated between -0.1 and $1.0 \mathrm{mS} / \mathrm{cm}$ for the recycled treated solutions. In the non-recycling system conductivity fluctuated between 0.2 and $1.1 \mathrm{mS} / \mathrm{cm}$.

Electrical conductivity values of this crop must be between 2.0 and 3.5 $\mathrm{mS} / \mathrm{cm}$ according to water quality and plant development stage (Martínez \& García, 1993; Shirazi et al., 2010). Those values increase between 0.5 and 1.0 in the substrate which coincides with the results of this test.

An adjusted maintenance of nutrient solution is not easy because it is influenced by several factors such as substrate, climate conditions, nutrient interaction, etc (Marfà, 2000; Vergote \& Vermeulen, 2012).

According to Martínez \& García (1993), tomato plants can tolerate 


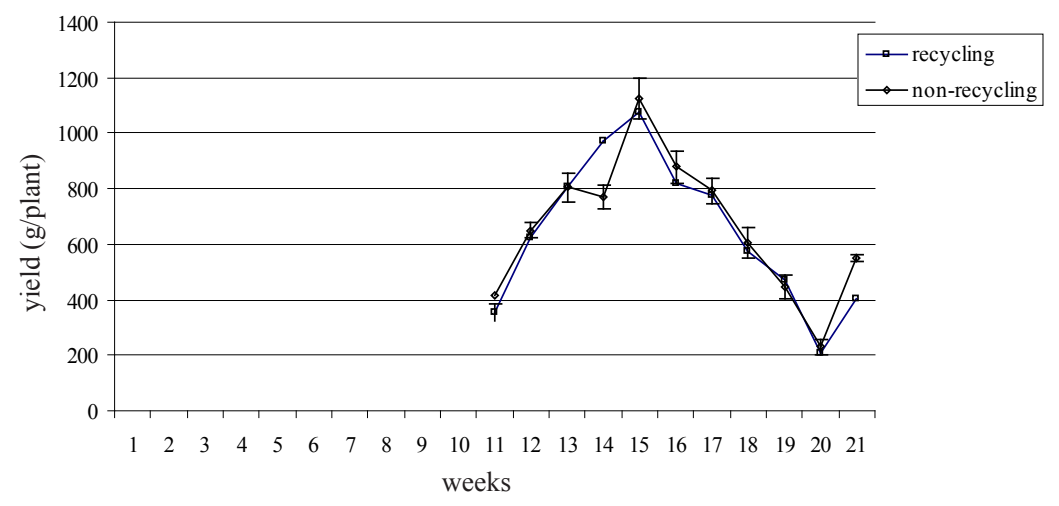

Figure 3. Average fruit yield per plant (g/plant) in both plots during the productive cycle [producción media de tomates por planta (g/planta) en las dos parcelas durante el ciclo productivo]. San Sebastián (Spain), Univ. de Valladolid, 2013.

Table 2. Size (\%) based collected tomatoes in both test plots and variance analysis for total fruit and size based tomato yield in the recycling and the non-recycling system (ns no significant, 95\%), (**significant, 99\%), (***significant, 99.5\%) [tomates recogidos $(\%)$ según el diámetro, en las dos parcelas de estudio y análisis de varianza para la producción total de tomates y para la producción según calibres, en el tratamiento con recirculación y sin recirculación de nutrientes ( ${ }^{(\mathrm{n}}$ no significativo, 95\%), (** significativo, 99\%), (*** significativo, 99,5\%)]. San Sebastián (Spain), Univ. de Valladolid, 2013.

\begin{tabular}{lrrrrrrr}
\hline & \multicolumn{2}{c}{ Recycling Non-recycling } & & \multicolumn{3}{c}{ Variance } \\
\cline { 2 - 3 } \cline { 6 - 7 } & \multicolumn{3}{c}{$\mathbf{( \% )}$} & & SS & df & P \\
\hline Diameter $>77 \mathrm{~mm}$ & 82.73 & 72.68 & & 885.2858 & 23 & $0.1895 \mathrm{~ns}$ \\
Diameter $67-77 \mathrm{~mm}$ & 13.48 & 14.53 & & 47.0902 & 23 & $0.4694 \mathrm{~ns}$ \\
Diameter $57-67 \mathrm{~mm}$ & 3.18 & 10.37 & & 169.8726 & 23 & $0.0001 * * *$ \\
Diameter $<57 \mathrm{~mm}$ & 0.61 & 2.42 & & 20.3985 & 23 & 0.0069 & $* *$ \\
\hline Total production & 100 & 100 & & $19,916.6251$ & 23 & $0.7810 \mathrm{~ns}$ \\
\hline
\end{tabular}

conditions where the main salts are sulfates. Sulfur can be stored in their organs with hardly any variation in their production.

The average weekly yield per plant, represented by tomato weigh collected during the cultivation in both nutrient solution recycling and non-recycling treatments were presented in figure 3 . Weekly average yield varied between 205.6 and 1,124.8 g/plant. The average yield obtained in the recycling system is $7.08 \mathrm{~kg} /$ plant facing $7.26 \mathrm{~kg} /$ plant in the non-recycling system. There were no significant differences.

Fruit yield follows a similar course in both treatments and the decrease obtained in week 14 in the non-recycling treatment could be due to a temperature decrease that affected more these plants.

Production decrease observed after the maximum production peak coincides with the behavior found by other authors (Riga \& Anza, 2004).
Total fruit yield does not present significant differences in both treatments which coincide with the results obtained by Macías (1997) in tomato crop in Andalucía. Giuffrida \& Leonardi (2009) did not find significant differences neither in fruit yield nor in mineral composition of cultivated leaves with or without recirculation in a rock-wool and turf substrate, and even a $40 \%$ reduction in nutrient supply. Regarding fruit yield, no significant differences were found, results that agree with other authors results (Marfà, 2000; Riga \& Anza, 2004; Dhakal et al., 2005).

Production per plant was very similar to the one found for Jack variety by Riga \& Anza (2004).

The percentage of size based tomato yield is presented in table 2. Tomatoes with a diameter between $57-67 \mathrm{~mm}$ reached $10 \%$ in the non-recycling system facing to the $3 \%$ in the recycling system. Waste fruit production was a lot higher in the non-recycling area.

Harvest began on 19/05 and ended on $20 / 07$ in 2012 . The increase at the end (week 21) is due to the recollection of all the fruits to uproot the plants to start a new crop.

Tomato size based production was $10 \%$ less in the plot without recirculation for the larger diameter tomatoes which can be correlated with a higher conductivity in this plot. According Papadopoulos \& Rending (1983) fruit size decreases as a consequence of salinity, $4 \mathrm{mS} / \mathrm{cm}$ conductivity decreases $10 \%$ fruit yield while $8 \mathrm{mS} / \mathrm{cm}$ conductivity decreases fruit yield in 50\% compared to normal yield.

In table 2 the results of the ANOVA carried out with fruit yield and sized based fruit production are shown for both treatments with 12 repetitions per treatment. There are no significant differences regarding total fruit yield in both treatments. An analysis of size based production shows that there are no significant differences for tomatoes with diameter $>77 \mathrm{~mm}$, nor in that ones between $67-77 \mathrm{~mm}$ diameter. There were differences in the tomatoes with diameter 57-67 mm, where there was a $226.1 \%$ higher production in the non-recycling area compared to the recycling area. This is the minimum commercialized diameter. In lower size, there were no marketable differences between one cultivation method and the other.

Os (1994) indicated that recirculation is more viable in vegetable crop and cut flower where plant density is low such as tomato, cucumber and rose bush, and it is not recommendable in lettuce where plant density is higher.

Recirculation has allowed reducing water and fertilizers supply with the subsequent economic saving and environmental impact minimization.

Differences in the total fruit yield in both treatments are not significant. There are significant differences for the total size based marketable yield, showing a higher value in the nonrecycling area.

The established simple nutrient recycling system can be considered as a practical alternative to the conventional 
cropping practice using open fertigation.

\section{ACKNOWLEDGEMENTS}

We are very grateful to D. Domingo Merino, D. José Antonio Odriozola, the Agronomic Laboratory de la Diputación Foral de Gipuzkoa, and the GILBE society.

\section{REFERENCES}

ALARCÓN AL. 1998. Tendencias de la fertirrigación española. Horticultura 133: 38-51.

CASANOVAS F. 1996. Abono del tomate en cultivo sin suelo. Hortoinformación 79: 39-42.

COSTA JS; JUNQUEIRA AMR. 2000. Diagnóstico do cultivo hidropônico de hortaliças na região do Distrito Federal. Horticultura Brasileira 18: 49-52.

DHAKAL U; SALOKHE V; TANTAU H, MAX J. 2005. Development of a greenhouse nutrient recycling system for tomato production in humid tropics. Agricultural Engineering International Journal 5: 1-15.

FELTRIN VP; BERTOLDI FC; SHIBATA M; RIZELIO VM; BARCELOS-OLIVEIRA
JL; SANT'ANNA ES. 2012. The ionic concentration influences of nutrient solution on the physico-chemical characteristics and productivity of two cherry tomato cultivars cutivated in NFT hydroponic system. Acta Horticulturae 947: 269-276.

GIUFFRIDA F; LEONARDI C. 2009. Nutrient solution concentrations in soilless closed system. Acta Horticulturae 807: 463-467.

GRAHAM T; ZHANG P; WOYZBUN E; DIXON M. 2011. Response of hydroponic tomato daily applications of aqueous via drip irrigation. Scientia Horticulturae 129: 464-471.

MACÍAS H. 1997. Recirculación de soluciones nutritivas. I parte. Horticultura 120: 13-20.

MARFÀ O. (coord). 2000. Recirculación en cultivos sin suelo. Réus: Ed. Horticultura, $177 \mathrm{p}$.

MARTÍNEZ E; GARCÍA M. 1993. Cultivo sin suelo: hortalizas en clima mediterráneo. Réus: Ed. Horticultura. 123p.

OS EA. 1994. Closed growing systems for more efficient and environmental friendly production. Acta Horticulturae 361: 194-200.

PAGE G; RIDOUTT B; BELLOTTI B. 2011. Fresh tomato for the Sydney market: An evaluation of options to reduce freshwater scarcity from agricultural water use. Agricultural Water Management 100: 18-24.

PAPADOPOULOS AP; HAO X; TU JC; ZHENG J. 1999. Tomato production in open or closed rockwool cultive system with NFT or rockwool nutrient feeding. Acta Horticulturae 481: 577-585.

PAPADOPOULOS AP; RENDING VV. 1983. Tomato response to soil salinity. Agronomy Journal 75: 696-700.

RESH HM. 1997. Cultivos hidropónicos. Madrid: Ed. Mundi-Prensa. 509p.

RIGA P; ANZA M. 2004. Cultivo de tomate bajo condiciones atlánticas. Vida Rural 189: 26-27.

SAS Institute 1999. SAS/STAT user's guide, version 8. Cary, NC: SAS Institute Inc. 250p.

SHIRAZI SS; RONAGHI AM; GHOLAMI AS; ZAHEDIFAR M. 2010. The influence of salinity and nitrogen on tomato fruit quality and micronutrients concentration in hydroponic culture. Journal of Science and Technology of Greenhouse Culture 1: 11-22.

SONNEVELD C; STRAVER N. 1992. Nutrient solutions for vegetables and flowers grown in water or substrate. Proefstation voor Tuinbouw onder Glas te Naaldwijk, The Netherland. Series: Voedingsoplossingen Glastuinbouw 8: 1-45.

VERGOTE N; VERMEULEN J. 2012. Recirculation aquaculture system (RAS) with tilapia in a hydroponic system with tomatoes. Acta Horticulturae 927: 67-74.

ZAHEDIFAR M; RONAGHI A; MOOSAVI AA; SHIRAZI SS. 2012. Influence of nitrogen and salinity levels on the fruits yields and chemical composition of tomato in a hydroponic culture. Journal of Plant Nutrition 35: 2211-2221. 